\title{
Effect of L-arginine on improvement of alveoli capillary wall thickness
}

\author{
Sri Sulistyowati, Yasir Avisena, Supriyadi Hari R \\ Department of Obstetrics and Gynecology, Faculty of Medicine, Sebelas Maret University, \\ Dr Moewardi Hospital, Surakarta
}

\begin{abstract}
ABSTRAK
Tujuan: Untuk membuktikan pengaruh pemberian L-Arginine terhadap perbaikan edema paru pada mencit model preeklampsia.

Bahan dan Metode: Penelitian eksperimental analitik, dilakukan pada 30 mencit bunting yang dibagi dalam 3 kelompok yaitu 10 mencit bunting normal (K1), 10 mencit bunting model preeklampsia (K2), dan 10 mencit bunting model preeklampsia yang mendapat terapi L-Arginine (K3). Semua subjek diperiksa ketebalan dinding kapiler alveoli pada parunya menggunakan metode Immunohistokimia. Hasil dianalisis menggunakan uji Kruskal Wallis dan Mann Whiteney.

Hasil: Rerata ketebalan dinding kapiler alveoli (K1) 5.01 \pm 1.76 $/ \mu \mathrm{m}$, (K2) $11.57 \pm 7.11 / \mu \mathrm{m}$, dengan nilai $\mathrm{p}=0.00$. Rerata ketebalan dinding kapiler alveoli (K3) 7.90 $\pm 4.10 / \mu \mathrm{m}$ dengan nilai $\mathrm{p}=0.01$.

Simpulan: L-arginine berpengaruh terhadap perbaikan edema paru pada mencit model preeklampsia yaitu berkurangnya ketebalan dinding kapiler alveoli paru. (MOG 2017;25:25-29)
\end{abstract}

Kata Kunci: L-Arginine; preeklampsia; edema paru

\begin{abstract}
Objectives: This study aims to demonstrate the effect of LArginine on pulmonary edema on mice preeclampsia model.

Materials and Methods: This experimental analytic study was conducted on 30 pregnant mice divided into 3 groups, namely 10 normal pregnant mice (K1), 10 pregnant mice preeclampsia model (K2), and 10 pregnant mice pre-eclampsia model who received LArginine (K3) therapy. All subjects examined the thickness of the alveoli capillary wall in their pulmo using the Immunohistochemical method. The results were analyzed using Kruskal Wallis and Mann Whiteney tests.

Results: Average alveoli capillary wall thickness (K1) $5.01 \pm 1.76 / \mu \mathrm{m}$, (K2) $11.57 \pm 7.11 / \mu \mathrm{m}$, with p value $=0.00$. Average alveoli capillary wall thickness (K3) $7.90 \pm 4.10 / \mu \mathrm{m}$ with $\mathrm{p}$ value $=0.01$.

Conclusion: L-arginine affects to improve pulmonary edema in preeclampsia by reducing alveoli capillary wall thickness of the pulmonary in mice model. (MOG 2017;25:25-29)
\end{abstract}

Keywords: L-Arginine; preeclampsia; pulmonary edema

Correspondence: Sri Sulistyowati, Department of Obstetrics and Gynecology, Faculty of Medicine, Sebelas Maret University, Dr Moewardi Hospital, Surakarta. E-mail: elis_spog@yahoo.co.id

\section{INTRODUCTION}

Preeclampsia is a multisystem abnormality in pregnancy characterized by a new onset of hypertension and protein in the urine that occurs after 20 weeks of gestation. Preeclampsia is still a major cause of both maternal and fetal mortality and morbidity. ${ }^{1}$

The exact etiology of preeclampsia remains unclear, with endothelial dysfunction plays an important role in the development of preeclampsia. ${ }^{2}$ Until now there has been no effective treatment for prevention and treatment of preeclampsia, besides fetal and placental delivery. ${ }^{3}$

In normal pregnancy, good placental oxygenation is required. However, Reactive Oxygen Species (ROS) which are derived from high oxygen fluctuations are also required for replication, proliferation, cell maturation, as well as embryonic development and pregnancy maintenance. ${ }^{4}$ ROS such as nitric oxide (NO), superoxide (O2), hydrogen peroxide (H2O2), hydroxyl radical $(\mathrm{OH})$, are molecules that regulate various functions in human physiology. ${ }^{5} \mathrm{ROS}$ signal is directly controlled by antioxidants in the body as a defense.
During normal pregnancy, the generation of ROS increases and is required for proper physiology. ${ }^{6}$

Preeclampsia is associated with increased oxidative stress. Reactive oxygen species, known as ROS, play an important role in this process. This reactive oxygen plays a role in cellular placenta, differentiation, apoptosis and also plays a role in determining the outcome of pregnancy. Relative hypoxia in the placenta is associated with inadequate uteroplacental circulation which causes maternal endothelial disorders. ${ }^{7}$ In preeklampsia there is an imbalance between endogenous antioxidants and pro-oxidants. This process occurs because a prooxidant species called ROS is much higher than that of endogenous antioxidant resis-tance. ${ }^{5,8,9}$

Today, endothelial dysfunction in preeclampsia is thought to be due to the relative deficiency of the available NO, and excessive peroxinitrite (ONOO). The combination of NO deficiency and an increase in ONOO directly or indirectly can lead to physiological and pathological changes associated with preeclampsia, platelet dysfunction, increased thromboxane (TXA) and endothelin and decreased prostacyclin (PGI2). In preeclampsia, endothelial dysfunction causes a decrease 
in the formation of vasodilator molecules such as NO, which is one of the vasoactive mediators of the endothelium. In pregnancy accompanied by preeclampsia, there is an increased synthesis of asymmetric dimethyl arginine (ADMA). ADMA is an endogenous inhibitor of NOS, which lowers NO synthesis. ${ }^{10}$

Nitric Oxide is an endogenous vasodilator synthesized from the essential amino acid L-Arginine using enzyme called nitric oxide synthase (NOS) as mediation. Larginine is a precursor amino acid of NO. The enzymatic pathway of L-arginine affects the formation of NOS. In patients with elevated ADMA, L-arginine competes with ADMA for NOS, resulting in increased NO number. ${ }^{11}$

In preeclampsia with pulmonary edema complications there are 3 causes of pulmonary capillary permeability edema, cardiogenic edema, or a combination of both. Most women with severe preeclampsia will have pulmonary edema (dilatation of pulmonary veins and alveolar walls) due to permeable edema. This is due to the normal changes in pregnancy that are exacerbated by the syndrome of preeclampsia. It is important to note that plasma oncotic pressure drops significantly in normal aterm pregnancies due to a decrease in serum albumin levels, and the oncotic pressure drops even more severely in preeclampsia. In addition, the increase of both extravascular fluid oncotic pressure and capillary permeability have been found in women with preeclampsia. $^{12}$

This study aims to determine the effect of L- L-Arginine plays a role in L-arginine-nitric oxide pathway in preeclampsia. Numerous studies show that NO production increases in normal pregnancy. In mice, the levels of plasma and urine cGMP (a second messenger NO) and levels of urine nitrite/nitrate, NO metabolites, indicators of NO production in the body, will increase during pregnancy. In addition, the expression of renal proteins (iNO and nNOS) would increase by $31 \%$ and $25 \%$, respectively, in mice in the middle of gestation. NO is shown to play an important role in mediating systemic hemodynamic and renal vasodilation during pregnancy. In preeclampsia, NO production outages due to the possibility of accumulation of ADMA, an endogenous inhibitor of eNOS, due to increased arginase activity, a deficiency on the substrate Larginine; a deficiency in the required cofactors for NOS activity and to increased oxidative stress is responsible for the rapid degradation of nitric oxide due to the high reactivity with $\mathrm{O} 2$ to form peroxynitrite which affects an increase in oxidative stress in preeclampsia, decreased enzyme expression antioxidant. ${ }^{13}$
Arginine on pulmonary edema improvement. LArginine is expected to be one of the solution of pulmonary edema therapy in preeclampsia.

\section{MATERIALS AND METHODS}

This experiment used analytical method and was conducted on January-February 2017 at Experimental Animal Cage and Anatomy Pathology Laboratory, Faculty of Veterinary Medicine, Airlangga University.

Research on animals trial using lung mice that meet the inclusion criteria which comes from Swiss strain female mice (Mus musculus) obtained from Veterinaria Farma center Surabaya. This study used female mice aged 3 months, healthy, weighing 20-25 grams. Sampling was done on lung of mice which were previously dissected, blocked in paraffin, and stained with Hematoxylin Eosin (HE). Based on the replication formula of Steel and Torrie, the sample size was 30 samples, which are divided into 3 groups: first group (K1) of normal pregnant mice, second group (K2) of preeclamptic pregnant mice and third group (K3) of preeclamptic mice model which had received L-Arginine 200 $\mathrm{mg} / \mathrm{kgbw} /$ day orally. On the 16th day of mice pregnancy, we performed surgery towards the three groups and the lungs were taken. The reason for taking it on the 16 th day is because it is assumed to be like a second trimester pregnancy in human pregnancy, where in the second trimester the manifestations of preeclamp-sia have appeared in humans.

To make mice pregnant, the lust is synchronized. 3months-old adults mice weighing 20-25 grams were injected with 5 IU Pregnant More Serum Gonadotropin (PMSG) hormone, 48 hours later were injected with 5 IU Human Chorionic Gonadotropin (hCG). Lust synchronized female mice were mated with 7 months male mice weighing \pm 60 grams. 17 hours afterwards, it can be diagnosed pregnant when there is copulatory plug (a plug covering the vaginal mice from the cervix to the vulva).

On the 1st day of pregnancy, all samples were divided into three groups: 10 normal pregnant mice (K1) which were kept without intervention, 20 preeclampsia model pregnant mice (given anti 10 ng iv Qa- 2 on the first until the fourth day of pregnancy to make preeclampsia model mice and divided into K2 and K3 groups). On day 12 to 15 of pregnancy, the mice in preeclampsia model group were given L-Arginine $200 \mathrm{mg} / \mathrm{kgbw} /$ day orally (10 K3 mice). On day -16 , the pregnancy was terminated in all three groups. The mice were then eutanated using ketamine and followed by necropsy. 
After opening the abdominal cavity, the lung was taken and inserted into pot which already contains $10 \%$ Neutral Buffer Formalin. Immunohistochemistry examination was then done. Reagents/Kit used were anti-Qa2 antibody kit (5K44), recombinant VEGF 121 kit (Recombinant mouse) as much as $125 \mathrm{mg} / \mathrm{kgBW}$ Xeno-free $^{\mathrm{TM}}$. Pregnant More Serum Gonadotropin (PMSG) PG 600, Hu Man Chorionic Gonadotropin (hCG) and L-arginine biosarginine Kit were given 200 $\mathrm{mg} / \mathrm{kgb} /$ day per oral.

\section{Immunohistochemistry}

The preparation of histologic preparations was performed by fixing lung organ using a $10 \%$ Neutral Buffer Formalin solution then cut and put into a plastic specimen. Furthermore, dehydration process was done using alcohol concentration of $70 \%, 80 \%, 90 \%$ alcohol absolute I, absolute II, 2 hours each, clarification was then done using xylol, and then printed using paraffins so that the preparations are printed in paraffin blocks and stored in the refrigerator. The paraffin blocks are then cut thinly as thick as 5-6 m using a microtome. The pieces are floated in warm water at $60^{\circ} \mathrm{C}$ to stretch and prevent the tissue from folding. The preparation is then removed and placed in a glass object to be stained with Hematoxylin and Eosin (HE). It is further examined under the Nikon Eclipse $\mathrm{Ci}$ light microscope with 400x magnification. Immunohistochemical examination was performed to measure the thickness of the alveolar pulmonary capillary wall.

Analysis of the data was done using oneway anova statistical test and Kruskal Wallis of SPSS (Software Package for social Science).

\section{Ethical Clearance}

Ethical clearance was achieved from ethical comission, Veterinary Mediciene Faculty, Airlangga University, number No. 648-KE, at November 152016.

\section{RESULTS AND DISCUSSION}

Alveoli capillary' wall images in normal pregnant mice (K1): no evidence of eosinophil proliferation (arrow) with thin (normal) alveolar capillary walls. In this preparation there is no pulmonary edema. In mice of preeclampsia (K2) model: massive eosinophil proliferation (arrows) is observed, causing swelling of the pulmonary alveolar wall capillaries. This illustrates pulmonary edema. In pre-eclampsia model mice with LArginine (K3): the proliferation of non-massif eosinophils is near-normal (arrows) so that the capillary walls of the lung alveoli are nearly normal in thickness. This preparation illustrates the improvement of lung edema.

Table 1. Mean of Alveolar Capilaries' Wall Thickness in K1, K2, and K3 Groups

\begin{tabular}{ccccc}
\hline \multirow{2}{*}{ Variables } & \multicolumn{3}{c}{ Groups } & $\mathrm{p}$ \\
\cline { 2 - 4 } K1 $(\mathrm{N}=10)$ & $\mathrm{K} 2(\mathrm{~N}=10)$ & $\mathrm{K} 3(\mathrm{~N}=10)$ & \\
\hline Alveolar & $5.01 \pm 1.76$ & $11.57 \pm 7.11$ & & $0.00^{*}$ \\
Capilaries' Wall & & $11.57 \pm 7.11$ & $7.90 \pm 4.10$ & $0.01^{*}$ \\
Thickness $(/ \mu \mathrm{m})$ & $5.01 \pm 1.76$ & & $7.90 \pm 4.10$ & 0.19 \\
\hline *Significancy $\mathrm{p}<0.05$ & & &
\end{tabular}

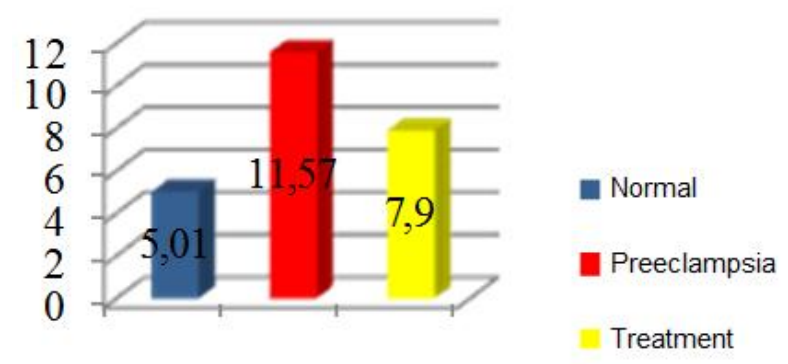

Figure 1. Mean of Alveolar Capilaries' Wall Thickness in K1, K2, and K3 Groups

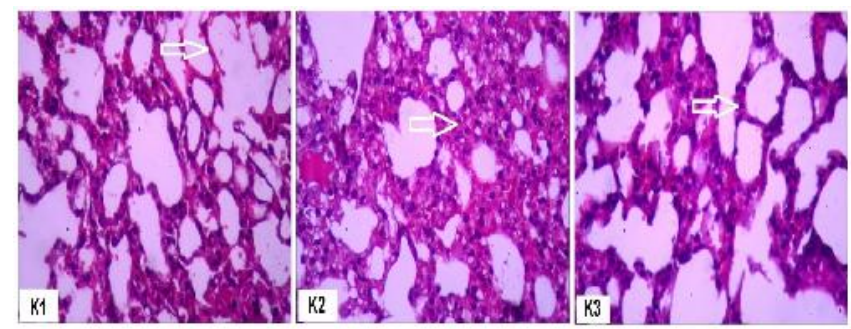

Figure 2. Alveoli capillary' wall images on examination using Nikon Eclipse Ci microscope as magnificator and Optilab Viewer 2.2 and raster image 3 as image processor.

Pulmonary edema is the leading contributor to maternal mortality in cases of preeclampsia. Pulmonary edema is associated with excessive administration of fluid and severity of the disease including HELLP syndrome and eclampsia. $^{14}$ The mechanism of pulmonary edema in preeclampsia is unclear, but the presence of angiogenic factors that enter the circulation, decreased colloid oncotic pressure, endothelial dysfunction or high intravascular pressure and high cardiac afterload may predispose pulmonary edema. ${ }^{15}$

Decreased colloid osmotic pressure after delivery due to the excessive blood loss or excessive administration of the crystalloid fluid is the trigger for pulmonary edema. In preeclampsia the incidence of pulmonary edema is increased due to increased leakage in capillaries and 
extravasation of fluid from capillaries caused by lung endothelial damage. ${ }^{16}$

L-Arginine acts as a NO precursor and is converted to NO and L-citrulline by NOS, which can prevent the occurrence of preeclampsia. This has been the focus of research aimed at investigating the role of prevention in women at high risk for preeclampsia. A study showed that dietary supplementation with L-Arginine and antioxidant combination was associated with a significant decrease in the incidence of preeclampsia, compared with self-antioxidants and placebo. ${ }^{17}$ Given that L-Arginine is a widely available food supplement, it makes L-Arginine a potential therapy to prevent preeclampsia. ${ }^{18}$

L-Arginine concentrations have been shown to be significantly reduced in women with preeclampsia when compared with normal pregnant women. Research with animal models try to show that L-Arginine-NO system undergo malregulation during pregnancy. Hypertension, proteinuria, IUGR and glomerular damage can occur due to the blockade of NO synthesis, while hypertension due to NO synthesis inhibition can be corrected with LArginine supplementation. In humans, administration of L-Arginine may improve uteroplacental circulation and decreasement of maternal blood pressure and oxidative stress may play a key role in the improvement of endothelial dysfunction and preeclampsia. ${ }^{19}$ Animal studies involving rats and mice have induced their animal models ith pre-eclampsia features, including hypertension, proteinuria and fetal growth restriction after inhibition of nitric oxide synthase activity. NGnitro-L-Arginine methyl ester (L-NAME) is an important inhibitor of nitric oxide synthase, this condition appears to be improved after administration of LArginine therapy ie reduced urinary protein excretion, significant reduction in blood pressure and restoration of glomeruli lesions; it is assumed to be because of LArginine, which acts through the nitric oxide synthase pathway by inhibiting the nitric oxide synthase inhibitor so that the production of nitric oxide will increase and vascular vasodilation, which improve hypoxia, can occur. $^{20}$

Hydrostatic pressure is determined by heart function in which the key components are preload, heart rate, heart rhythm, contrcatility, lusitrophy and afterload. Hydrostatic pressure is also determined by artery and vein's tone through the activity of the nervous system and the circulation of vasoactive substances. The function of systemic and pulmonary circulation in parallel, with cardiac output matching the venous return. The Starling frank mechanism allows matching of the two ventricular stroke volumes. This coupling mechanism means that either acute pulmonary edema or complete discharge from pulmonary circulation may occur, both of which can be fatal. A system in equilibrium represented by cardiac output is achieved in the ventricle end of the lower left diastolic pressure meeting the needs of tissue metabolism and the same venous return. Acute pulmonary edema or acute heart failure is an unbalanced system and is unable to meet the metabolic needs of tissues that, if left untreated, will lead to death. ${ }^{14} \mathrm{~L}$ Arginine may therefore be a new therapeutic option for hypertension in pregnancy to prevent the occurrence of preeclampsia.

In this study L-Arginine can improve pulmonary edema by the decreasement in pulmonary alveoli's capillary walls thickness in pregnant mice preeklampsia model. This is possible because L-Arginine acts through the nitric oxide synthase pathway by inhibiting the nitric oxide synthase inhibitor so that the production of nitric oxide will increase and can affect the occurrence of vascular vasodilation and improve hypoxia. ${ }^{20}$

L-Arginine concentrations have been shown to be significantly reduced in women with preeclampsia when compared with normal pregnant women. Research with animal models try to show that L-Arginine-NO system was malregulated during pregnancy. Hypertension, proteinuria, IUGR and glomerular damage can occur due to blockade of NO synthesis, while hypertension due to NO synthesis inhibition can be corrected with LArginine supplementation. In humans, administration of L-Arginine may improve uteroplacental circulation and decreasement of maternal blood pressure and oxidative stress may play a key role in the development of endothelial dysfunction and preeclampsia. ${ }^{19}$

\section{CONCLUSION}

L-arginine has an effect on the improvement of lung edema in preeclampsia model of mice, which is by the decreasement in the thickness of pulmonary alveoli' capillary walls.

\section{REFERENCES}

1. Adu-Bonsaffoh K, Antwi DA, Gyan B, Obed SA. Endothelial dysfunction in the pathogenesis of preeclampsia in Ghanaian women. BMC Physiol. 2017; 17: 5 .

2. Mateus J, Bytautiene E, Lu F, et al. Endothelial growth factor therapy improves preeclampsia-like manifestations in a murine model induced by overexpression of sVEGFR-1. Am J Physiol Heart Circ Physiol. 2011;301(5):H1781-7. 
3. Woods AK, Hoffmann DS, Weydert CJ, et al. Adenoviral delivery of VEGF121 early in pregnancy prevents spontaneous development of preeclampsia in $\mathrm{BPH} / 5$ mice. Hypertension 2011;57(1):94-102.

4. Mutinati M, Piccinno M, Roncetti M, Campanile D, Rizzo A, Sciorsci R. Oxidative stress during pregnancy in the sheep. Reprod Domest Anim. 2013;48(3):353-7.

5. Kalyanaraman B. Teaching the basics of redox biology to medical and graduate students: Oxidants, antioxidants and disease mechanisms. Redox Biology 2013;1(1): 244-57.

6. Yang X, Guo L, Li H, et al. Analysis of the original causes of placental oxidative stress in normal pregnancy and pre-eclampsia: a hypothesis. J Matern Fetal Neonatal Med. 2012;25(7):884-8.

7. Ekambaram P. HSP70 expression and its role in preeclamptic stress. Indian J Biochem Biophys. 2011;48(4):243-55.

8. Lappas M, Mitton A, Permezel M. In response to oxidative stress, the expression of inflammatory cytokines and antioxidant enzymes are impaired in placenta, but not adipose tissue, of women with gestational diabetes. J Endocrinol. 2010;204(1):7584.

9. Matsubara K, Matsubara Y, Hyodo S et al. Role of nitric oxide and reactive oxygen species in the pathogenesis of preeclampsia. J Obstet Gynaecol Res. 2010;36(2):239-47.

10. Villar J, Purwar M, Merialdi M, et al. World Health Organisation multicentre randomised trial of supplementation with vitamins $\mathrm{C}$ and $\mathrm{E}$ among pregnant women at high risk for pre-eclampsia in populations of low nutritional status from developing countries. BJOG 2009;116(6):780-8.

11. Camarena Pulido EE, García Benavides L, Panduro Barón JG, et al. Efficacy of L-arginine for preventing preeclampsia in high-risk pregnancies: A double-blind, randomized, clinical trial. Hyper-tens Pregnancy 2016;35(2):217-25.

12. Cunningham FG, Leveno KJ, Bloom SL. William Obstetrics. 24th Ed. United States: McGraw Hill Education; 2014. p. 762-68.

13. Elsa C, Matos MG, Garrido MR, Israel A. Rat kidney antioxydant enzyme activities in experimental preeclampsia. International Journal Of Current Medical And Pharmaceutical Research. 2015;1(7): 104-9.

14. Dennis AT. Solnordal CB. Acute pulmonary oedema in pregnant women. Anaesthesia 2012;67: 646-59.

15. Gandhi S, Sun D, Park AL, et al. The Pulmonary Edema Preeclampsia Evaluation (PEPE) study. J Obstet Gynaecol Can 2014;36(12):1065-70.

16. Devi DS, Kumar BV. A case of severe preeclampsia presenting as acute pulmonary oedema. Int $\mathbf{J}$ Reprod Contracept Obstet Gynecol. 2016;5(3):899902.

17. Vadillo-Ortega F, Perichart-Perera O, Espino S. Effect of supplementation during pregnancy with L-arginine and antioxidant vitamins in medical food on pre-eclampsia in high risk population: randomised controlled trial. BMJ 2011; 19;342: d2901.

18. Johal T, Lees CC, Everett TR, Wilkinson IB. The nitric oxide pathway and possible therapeutic options in pre-eclampsia. $\mathrm{Br} \mathrm{J}$ Clin Pharmacol. 2014;78(2):244-57.

19. Gui S, Jia J, Niu X, et al. Arginine supplementation for improving maternal and neonatal outcomes in hypertensive disorder of pregnancy: a systematic review. J Renin Angiotensin Aldosterone Syst. 2014;15(1):88-96.

20. Dorniak-Wall T, Grivell RM, Dekker GA, Hague W, Dodd JM. The role of L-arginine in the prevention and treatment of pre-eclampsia: a systematic review of randomised trials. J Hum Hypertens. 2014;28(4):230-5. 